\title{
RESETTLEMENT AND CARING FOR THE COUNTRY:
}

\author{
THE ANMATYERRE EXPERIENCE
}

\author{
Elspeth Young
}

Caring for country, the carrying out of traditional responsibility for the land, is a process of great importance for Aboriginal people. If the country is neglected it will become infertile and fail to provide sustenance; and the integrity of its spirit guardians and progenitors will no longer be maintained. Such truths are essential to the fabric of Aboriginal society. They form the basis for definition of Aboriginal traditional land ownership, conventionally understood by non-Aborigines to conform to recognised principles of inheritance, of which descent is perceived to be the most important. But adequately caring for country means being able to visit it and witness its preservation, living in close proximity to it where practical. This has not always been possible. Environmental, economic, political and social factors have, both before and since non-Aboriginal settlement, caused shifts in Aboriginal population and have forced people to adapt their systems of land inheritance accordingly.

Before the influence of non-Aboriginal society became strong, the system of land responsibility would, from time to time, have broken down because of the demise of key people in small population groups. When that occurred spiritual responsibility was transferred to other groups and individuals not necessarily linked to the former owners through descent. In addition the individual skills and capabilities of people were recognised, and only those with much to contribute would be taught all the ritual details which would then enable them to instruct others. This body of knowledge might well be witheld from others perceived to have little interest or skill in such matters.

Non-Aboriginal settlement has introduced other pressures leading to similar adaptations. The establishment of pastoral station homesteads, mining camps, telegraph stations and small towns caused Aborigines to move from their original country, sometimes virtually on a permanent basis. Many groups developed new distributions of birthplaces, conception places and places of residence, the spatial extent of which by no means corresponded with that of the country of their own ancestors or of the mythological beings associated with them In these new places people cared for the country, taking on a primary spiritual responsibility which otherwise they were unlikely to have held.

Transformations such as these demonstrate the essential dynamism of Aboriginal customary beliefs and practices. Their existence has come sharply into focus in the process of Aboriginal land claims, during which the conventionally accepted definitions of traditional land ownership have been challenged. The Aboriginal Land Rights (Northern Territory) Act 1976 states that before claimants can be granted freehold title to the territory for which they carry responsibility they must be able to prove that they are 'traditional owners'.

Dr Elspeth Young, a senior lecturer in Geography, University College, University of New South Wales, Australian Defence Force Academy, has, over the last decade, conducted research on contemporary socioeconomic transformation in remote Aboriginal communities. She has also worked as a consultant on Aboriginal land claims in Central Australia. 
According to Subsection 3(1) of the Act traditional owners are 'a local descent group of Aboriginals who

(a) have common spiritual affiliations to a site on the land, being affiliations that place the group under a primary spiritual responsibility for that site and for the land; and

(b) are entitled by Aboriginal tradition to forage as of right over that land.'

The interpretation of this definition, as Toohey ${ }^{1}$ comments, leaves scope for variations. However the conventional definition, accepted by Toohey in the earliest land claims under the Act such as the Warlpiri and Kartangarurru-Kurintji claim ${ }^{2}$ stresses spiritual affiliation transferred through the patriline, from father to children. Hiatt, ${ }^{3}$ along with others, attributes this narrow description to the acceptance of Radcliffe-Brown's interpretation of human-land relationships and inheritance of rights in Aboriginal society. In the course of subsequent land claims this definition has been questioned. A plea for the recognition of ambilineal descent groups, people who have inherited their responsibilities through either their mothers or fathers, was made for the Uluru claim $;{ }^{4}$ and later the Land Commissioner accepted that the children of women of a patrilineal descent group, commonly referred to as kurdungurlu in central Australia, also held spiritual responsibility for the land. While in the Utopia claim ${ }^{5}$ this was not interpreted as a 'primary' responsibility the later judgement on the Willowra claim ${ }^{6}$ did accept this definition in its entirety.

Changes such as these did much to bring the terms of the Land Rights Act closer to the reality of Aboriginal definitions of responsibility for land. However there remained other groups and individuals who, in the course of presenting evidence, claimed primary spiritual responsibility but did not even fit comfortably into these broader definitions of descent. They based their claims on birthplace, conception place, mythological links and a number of other avenues of descent. All of these, as Hiatt ${ }^{7}$ summarises, have been recorded in existing ethnographic material. But they have previously received only scant acknowledgement in anthropological interpretation. The need to reassess definitions of land ownership reflects, as Hiatt $^{8}$ acknowledges, the fact that their characteristics have been studied and analysed during a period of significant social change. Throughout the 20 th century structures of land ownership have continually been disrupted or even destroyed. It is therefore scarcely surprising that recent findings on these issues have increasingly had to accommodate the transformation resulting from the history of non-Aboriginal settlement.

Oral history provides a valuable body of knowledge about these changes and adaptations. During land claim hearings many people have described not only their lines of inheritance of land ownership and the responsibilities which these entail, but also events which have affected their contemporary residence patterns. These two components together account for present human-land relationships. They are inextricably linked. Here the stories of some of the

1 Toohey 1984:38.

2 Aboriginal Land Commissioner 1979.

3 Hiatt 1984b: 12.

4 Layton 1983.

5 Aborizinal Land Commissioner 1980a.

6 Aboriginal Land Commissioner $1980 \mathrm{~b}$.

7 Hiatt 1984b:21.

8 Hiatt 1984a:1. 
Anmatyerre people of central Australia are related, and considered in terms of responsibility for land. Most of the people concerned currently live in Mt Allan and Ti Tree, two Aboriginalowned pastoral stations recently the subjects of claims for re-designation as unalienable Aboriginal freehold land. ${ }^{9}$ Two main themes emerge. First, individual claimants, living in the community and universally accepted as holding spiritual responsibility for part of the land under claim have been cited as traditional owners although they did not conform to conventional lines of descent. Some of these cases have been accepted by the Aboriginal Land Commissioners and some rejected. ${ }^{10}$ Regardless of the legal interpretations behind acceptance or rejection, a prime reason why these claims were made was that, through the influence of the pastoral industry, these people had resettled on land other than that of their paternal and maternal ancestors.

Secondly in both claims many people accepted by descent as traditional owners of the land in question were acknowledged to have spent most of their lives living elsewhere. While this did not affect their recognition as traditional owners it did affect their knowledge of the country, both of its spiritually significant sites and of the economic resources which it contains. They might know little about the ceremonies, and associated songs, dances and illustrations and the evidence which they were able to present in land claim hearings might therefore be sparse and deficient. For them the land claim hearing provided a significant opportunity to learn from others, and compensate for the deficiencies in their knowledge of a vital part of their cultural inheritance. Ironically, as the stories from Mt Allan and Ti Tree demonstrate, a number of those responsible for this teaching process were the same people whose claims for recognition as traditional owners were most dubious, and in some cases ruled to be unacceptable within the terms of the Act.

\section{The Anmatyerre Mob: environment, social organisation and contact.}

The Anmatyerre people, whose language is closely linked to Arrernte (Aranda), live some $200 \mathrm{~km}$ to the north, northwest and northeast of Alice Springs in a number of communities located on pastoral stations (Figure 1). Mt Allan and Ti Tree, both on Aboriginal-owned stations are the largest Anmatyerre groups and their combined populations of between 450 and 500 would account for about 40 per cent of present day Anmatyerre. Both communities lie within land defined as Anmatyerre territory in customary terms but while Ti Tree lies at the heartland of that area, Mt Allan is on the extreme western edge, bordered to the west by Warlpiri country belonging to groups now resident in Yuendumu.

Compared to their Warlpiri and Arrernte neighbours the Anmatyerre are today a comparatively small population group, probably only about fourteen hundred altogether. Spencer ${ }^{11}$ commented that the Anmatyerre had declined in number even as early as the late 19 th century, a pattern which he attributed to the effects of drought in the 1880 s, coupled with population dispersal following conflict with early European settlers on Anmatyerre country. Meggitt ${ }^{12}$ also commented on the relatively small number of Anmatyerre, and suggested that the expansion of Warlpiri into western Anmatyerre country around Anningie

9 Peterson and Young 1982; Green et al. 1984

10 Aboriginal Land Commissioner 1985, 1987.

11 Spencer 1928:412.

12 Meggitt 1962:40. 
ANMATYERRE COUNTRY

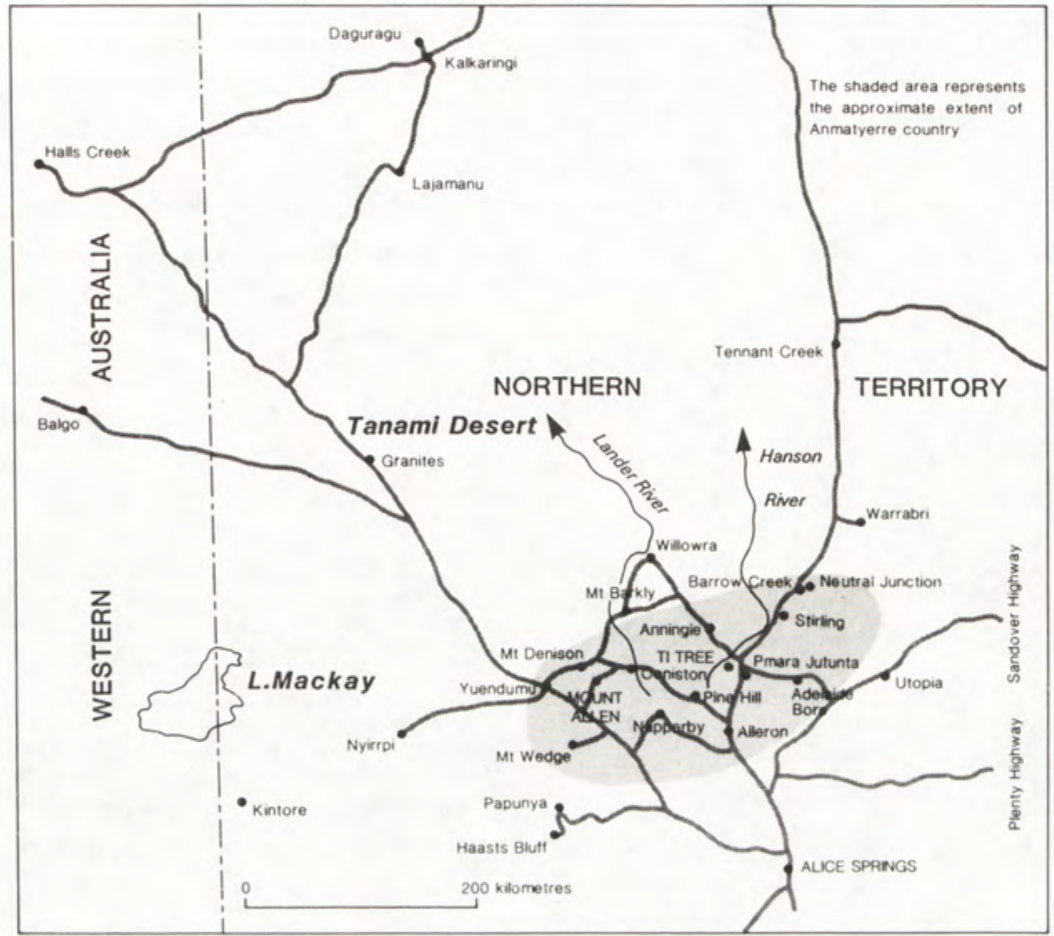

Figure 1: Anmatyerre country.

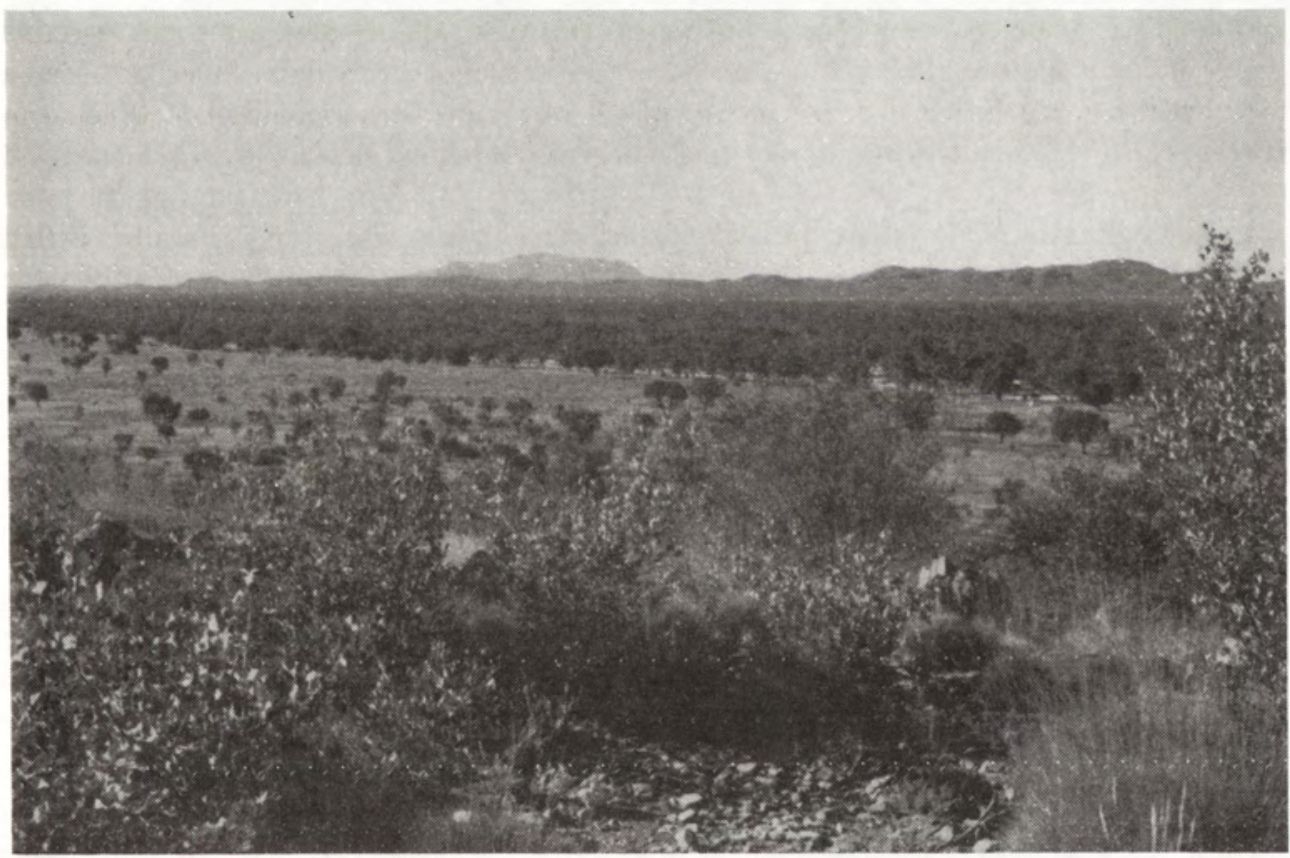

Anmatyerre country. 
had occurred partly because of population decline. This movement appears to have affected responsibility for land in that region, with both Warlpiri and Anmatyerre claiming traditional ownership. Intermarriage is another factor. As Meggitt further stated, this eastern Warlpiri expansion did not appear to have caused enmity, the two groups frequently intermarried and the Warlpiri apparently felt that the Anmatyerre were 'almost Warlpiri'. Although their languages belong to distinctly different families (Arandic and non-Arandic), Anmatyerre and Warlpiri social organisation is similar, with both being divided into eight major subsections forming two moieties between which preferred marriages occur. Linkages formed by marriage, either between Anmatyerre and Warlpiri, or between different Anmatyerre groups, led to linkages between different countries and created an interdependence which was a crucial element in carrying out ritual responsibilities. (Figure 2).

Figure 2 Warlpiri/Anmatyerre subsection terms ${ }^{13}$ and linkages.

\begin{tabular}{|c|c|c|c|c|}
\hline Warlpiri & Anmatyerre & & Warlpiri & Anmatyerre \\
\hline$\Gamma \mathrm{J} /$ Nampijinpa & Mpetyane & $=$ & $\mathrm{J} /$ Napangardi & Pengarte 7 \\
\hline$[\mathrm{J} /$ Nakamarra & Kemarre & $=$ & J/Napaljarri & Peltharre - \\
\hline L Ju/Napurrula & Perrwerrle & $=$ & J/Napanangke & Penangke $]$ \\
\hline L J/Nangala & Ngale & $=$ & J/Nungarrayi & Kngwarraye - \\
\hline
\end{tabular}

Anmatyerre country is, by central Australian standards, rich in water, game and vegetable foods. It was therefore attractive to non-Aboriginal settlers. The explorer Stuart ascended a prominent hill on the northern boundary of Ti Tree (later named Central Mt Stuart) in 1860 , and by 1870 surveyors of the route for the Overland Telegraph had also traversed Anmatyerre country from south to north. The first stock drovers arrived during the same year. Thereafter Anmatyerre territory came increasingly under pressure as pastoralists settled in the region, and conflicts occurred, particularly when drought caused competition for scarce water supplies. These led to Anmatyerre attacks on the Barrow Creek telegraph station (1874) and on the Annas Reservoir homestead which was burned to the ground in 1883. Reprisals following these attacks caused the population dispersal referred to by Spencer. However the formal establishment of the non-Aboriginal pastoral industry in the area, with the alienation of Anmatyerre land for cattle station leases did not occur until the early 20 th century. The leases on Pine Hill and Coniston were granted during the war years (1916 and 1917 respectively), Napperby station was set up in 1919 and Ti Tree followed in 1927. By 1933 almost all Anmatyerre country had been alienated for pastoralism But some western regions, in general with less accessible supplies of surface water, were still unalienated, although grazing licences had been established over them. Mt Allan, within this region, did not become a separate pastoral lease until 1949.

The alienation of Anmatyerre land, and the period when it occurred, had a profound

13 Warlpiri terminology distinguishes between males and females, designated by the initials $\mathrm{J}$ and $\mathbf{N}$ respectively (for example Jampijinpa and Nampijinpa); for Jupurrula and Napurrula the first vowel also changes; Anmatyerre terminology makes no such distinctions. 


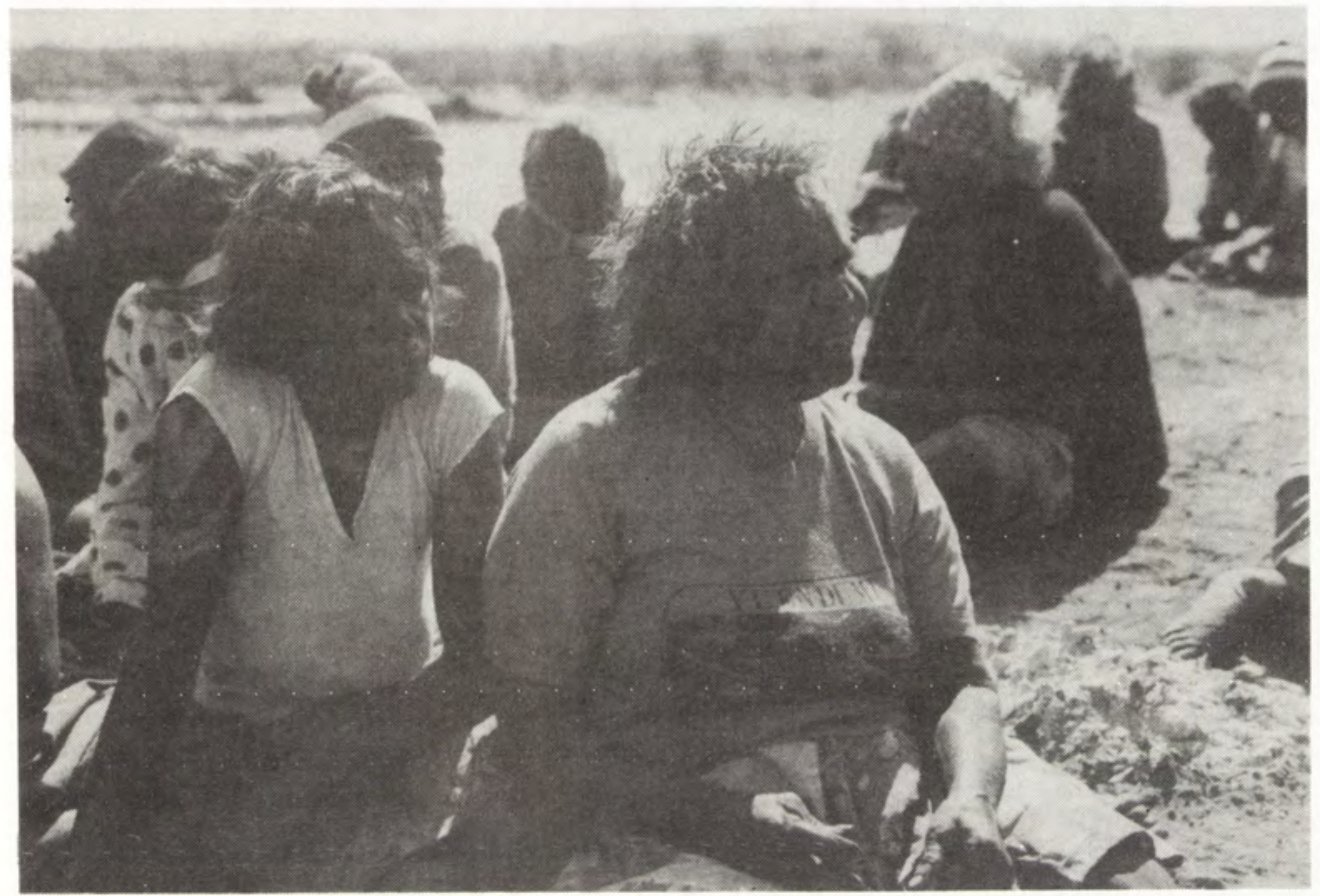

Napangardi and Napanangka giving evidence at Mt Allan claim.

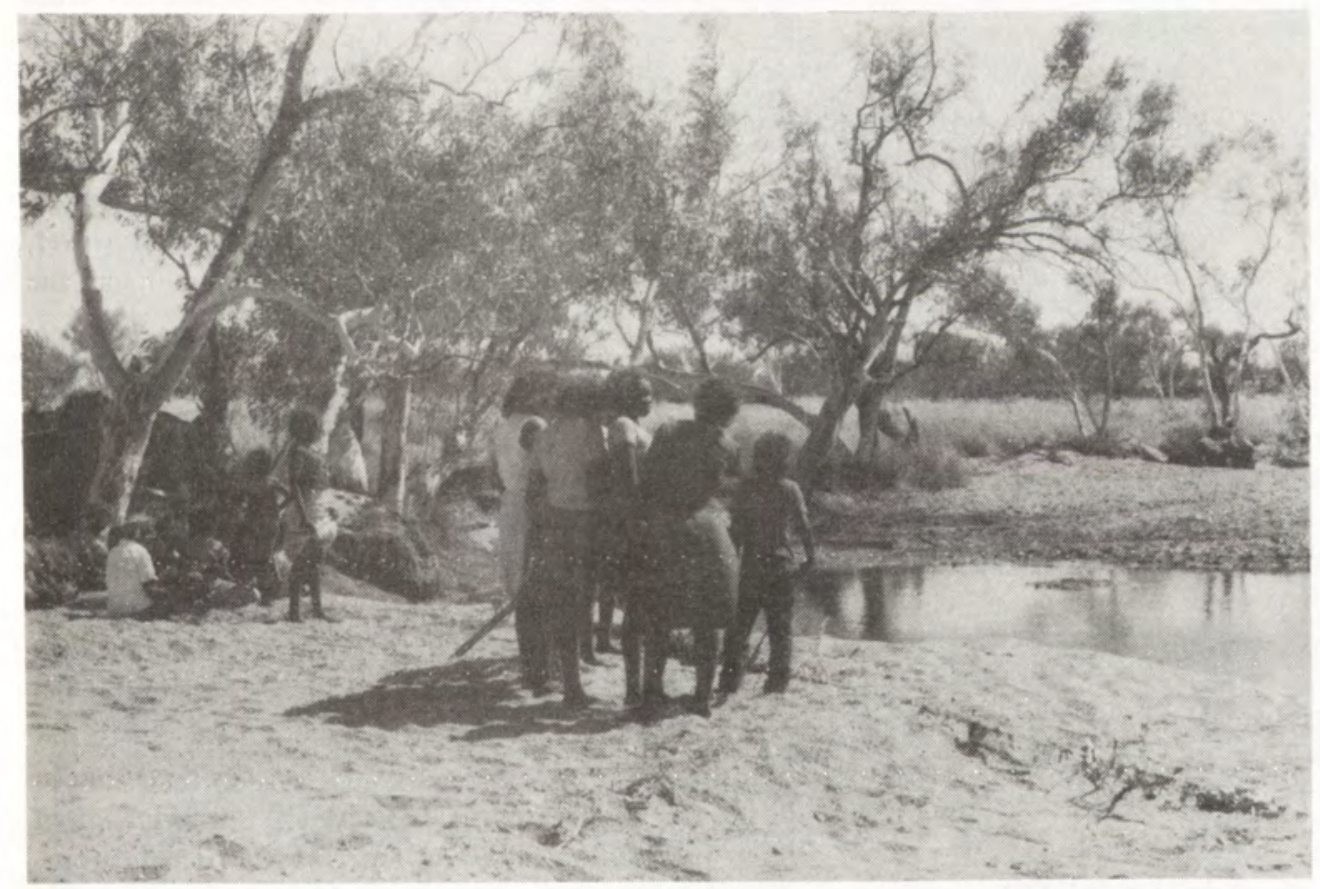

Angintye waterhole. 
effect on population distribution. In time of need, people congregated near the homesteads of the cattle stations, hoping to get rations of food and sticks of tobacco. Some adults began to work to develop the properties, both directly with the stock and in domestic jobs, and they became relatively permanent inhabitants of the homestead camps. Other members of their families visited frequently, and also joined these camps from time to time. People still ranged over other parts of Anmatyerre territory but the numbers involved would have been much smaller than before non-Aboriginal settlement. And as more and more of the land was alienated the possibilities for moving freely about their territory, and caring for it according to Aboriginal law became much more limited. The separate experiences of $\mathrm{Mt}$ Allan and Ti Tree people illustrate how these circumstances subsequently affected primary responsibility for land.

\section{Mt Allan.}

Resettlement had two main effects on the way in which customary land responsibility was conducted at Mt Allan; it caused some members of the local descent groups to take up residence elsewhere; and it led to the identification of other individuals who, long resident in the community and well versed in ritual knowledge, did not belong to the conventional local descent group but were accepted as traditional owners. The modern distribution of traditional owners of Mt Allan country is a good indication of the first element (Figure 3). In 1982 these people who were not at Mt Allan itself lived in comparatively large numbers at Laramba (Napperby) and Yuendumu, and in smaller groups in Pinehill, Willowra and Ti Tree. Some also lived in Alice Springs. According to oral accounts given by older members of these groups their families gathered at Pinehill, Coniston and Napperby when these stations were established prior to 1920. Coniston and Napperby homesteads were both located close to permanent waterholes/soakages in the beds of the Lander and Napperby rivers, places where Anmatyerre had always met for large ceremonial gatherings, and which were important camping spots in times of drought. These two stations therefore drew Aborigines to places with which they were already familiar, and which were of considerable religious significance for them in any case. Mt Allan country, with no large permanent waterholes and no station homestead with tobacco and rations, was thereafter used only periodically. However, important sacred sites on Mt Allan were still cared for, ceremonies were maintained, and the knowledge was held, at least among older generations.

In 1946 another settlement, Yuendumu, was established under government auspices close to Mt Allan. Although planned principally for Warlpiri people who had already gathered at ration depots at Tanami, over $400 \mathrm{~km}$ to the northwest, others also came to Yuendumu. In particular Anmatyerre, traditional owners of country within the reserve surrounding the new settlement, gathered there as a principal local land owning group. These people were also traditional owners of adjacent country on Mt Allan. A final significant element in the resettlement story is the transfer of part-European Anmatyerre children to Alice Springs under assimilation practices. Such children were institutionalised in the town from the 1940s onwards and, although they maintained contact with their Anmatyerre relatives back on the cattle stations, became part of the urban population.

This pattern of settlement was well established when the Mt Allan lease was taken out in 1949. According to D.D. Smith, son of the first station owner, the country was uninhabited when his family arrived. He and his father went to Yuendumu to recruit Aboriginal labour, and returned to Mt Allan with a number of families, all of whom were related to each other 


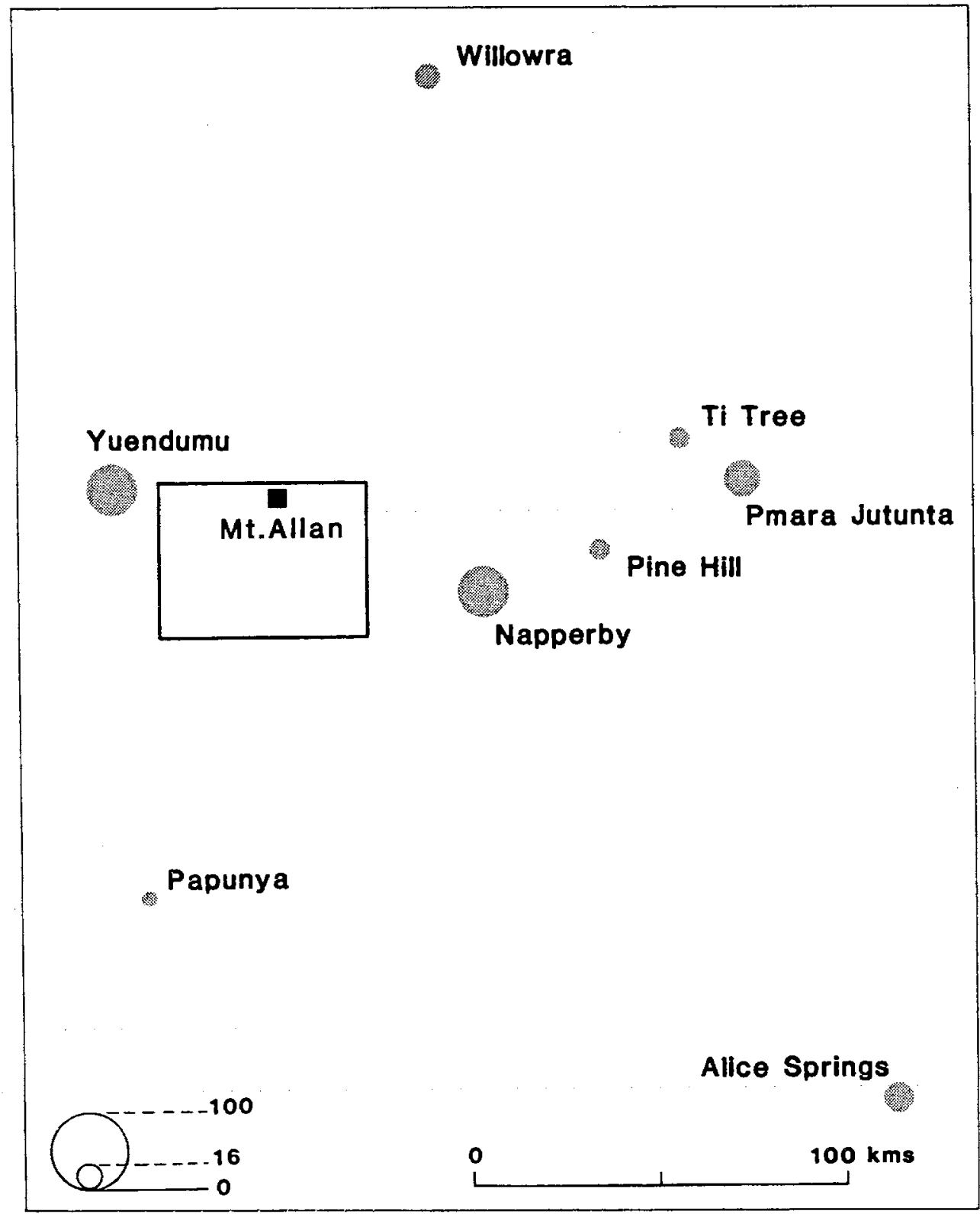

- Darwin

- Now Zealand

Figure 3: Traditional owners of Mt Allan country living outside the community. Size of circle indicates numbers of people. 
and were traditional owners of parts of the new lease. These families formed the core of the new workforce, and have remained in that position ever since. They had returned to their country.

The experiences of other Mt Allan people were different. Those who had moved to Coniston at an early stage intermarried with traditional owners of Coniston country, and remained there with their relatives as part of the labour force. Although such intermarriage patterns would have occurred before non-Aboriginal settlement, the change of residence would have been less clearly established. They developed a strong attachment to Coniston, one which survived even the aftermath of the massacre following the killing of Brooks, the dingo scalp collector, on neighbouring Mt Denison in $1928 .^{14}$ They 'grew up' Coniston station, and certainly were involved in the maintenance of ceremony there as well as periodically back on Mt Allan. But in the 1960s things changed. The station changed hands and, coupled with the introduction of award wages for Aboriginal stockmen, a large Aboriginal population was no longer welcome at Coniston. These families dispersed, some returning to Mt Allan and others to neighbouring stations such as Willowra and Mt Denison. Today there is no permanent Aboriginal population at Coniston. Mt Allan families who had gone to Napperby, however, remained there. One of these families, represented in the 1980 s by eight siblings and their descendants, described how their father, 'Old Jangala', whose country lay partly in eastern Mt Allan and partly in western Napperby, had settled at the homestead in the early years and had become one of the key stockworkers. They were all born there, and were brought up knowing something of the lore concerning sites on Napperby itself. But they never visited that part of their father's country on Mt Allan. Subsequently some members of this family dispersed, some to $\mathrm{Ti}$ Tree, and, in the case of those of part-European descent, to Alice Springs. None then went back to Mt Allan.

The final element in the Mt Allan resettlement history stems from the purchase of the station by the Aboriginal Land Fund Commission in 1976, and the subsequent land claim. Following the purchase some Mt Allan families, principally those who had been working on Mt Denison, returned, thereby reinforcing the maintenance of ceremonial responsibility for Mt Allan country. That move was regarded with scepticism by some non-Aborigines, who attributed it to a desire to share in the monetary profits which might be available. As far as the Anmatyerre were concerned, it was a move essential to the maintenance of the true 'law' in that area. The land claim process itself kindled further feelings about the need for traditional owners to be living back on their own country, and led to the establishment of two homeland centres on Mt Allan, one of which was set up by members of 'Old Jangala's' family, who had until then lived all their lives on Napperby. Alice Springs based members of this family have also recently spent lengthy periods back on the station.

In terms of the ritual knowledge of Mt Allan's traditional owners this rather complicated history of population movement has been important. During the collection of evidence for the land claim it became clear that a high proportion of the traditional owners living at Mt Allan itself were descended through either their fathers or mothers from the $\mathrm{J} / \mathrm{Napangardi}$ and $\mathrm{J} /$ Napanangka groups whose major responsibility was the honey-ant dreaming sites on

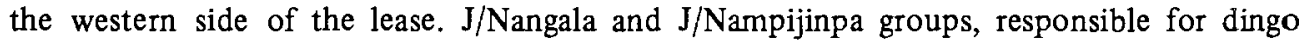
dreaming sites on the eastern side, were living, as already mentioned, in Napperby, and 


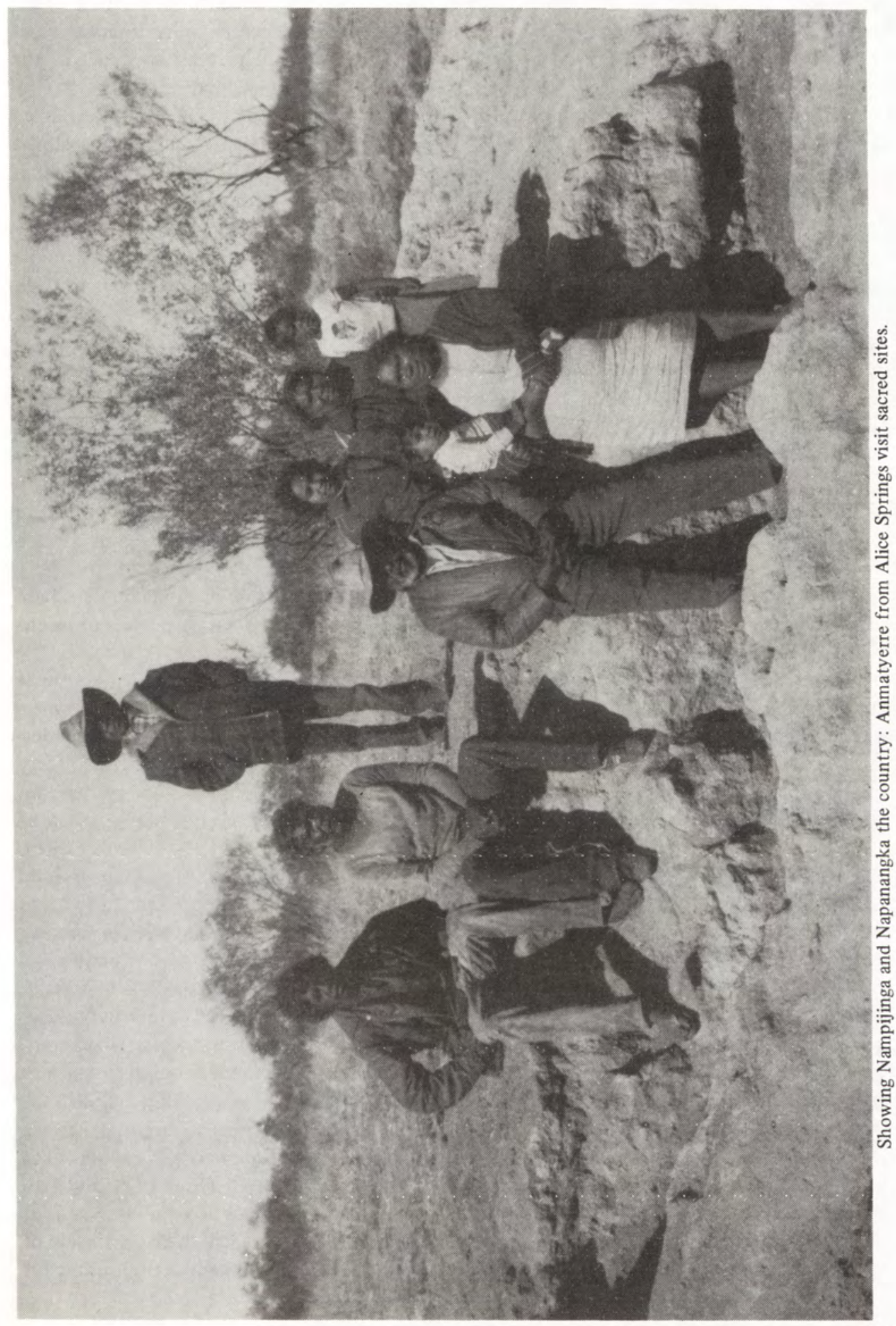


$\mathrm{J} /$ Nungarrayi and J/Napaljarri groups, whose country covers the southern portion of $\mathrm{Mt}$ Allan, were mostly in Napperby or Yuendumu. When these people were interviewed it became clear that few of the dingo dreaming group had much direct knowledge of the country in question, and some of the third group were in the same situation.

The problem was particularly severe for the women, who on marriage had often moved even further afield and had had little contact since. But once intense discussions began the community solved the problem according to their own convention. It became clear that one old man, resident on Mt Allan ever since the start of the station and himself holding primary spiritual responsibility for honey-ant dreaming sites, was also extremely knowledgable in much of the other lore. Thereafter he deliberately worked with members of the other groups, accompanying them on site visits, relating the stories of the travels of their mythical ancestors and even pointing out where previous members of their families had passed away. Much of this information was already known to those concerned, but they had never had the opportunity to actually visit the country and see the places about which they had learned while growing up far away. The experience was particularly poignant for those Anmatyerre who, because of their European ancestry, had been moved to Alice Springs. For the first time they not only heard the songs and watched the dances which celebrated the spirits of their country, but also travelled through it and gained a new identification of prime importance to them. Altogether the transmission of knowledge needed to support the land claim was of vital importance for the future survival of Anmatyerre customs and beliefs in the area. People were able to learn not only lore handed down orally through generations, but could examine these stories in their spatial context. The false separation between lore and primary knowledge of country, essentially an artefact of recent resettlement, ceased to exist.

As the above examples suggest, residence on the country could be an important element in gaining the ritual and ecological knowledge needed to demonstrate traditional ownership. The Mt Allan community in 1982 also included many people who could not, by descent, claim to be traditional owners but who had lived there for between thirty and forty years and clearly had a very deep understanding of these matters. A number of these individuals were listed by the Anmatyerre as traditional owners. They included a group of women, all Nungarrayis, who were the wives of a number of the first Mt Allan stockmen, many of whom were Jangalas. Some of these women were Warlpiri and some Anmatyerre, and the country of their parents and grandparents included areas around Nyirrpi. (150km to the west of Yuendumu), Mt Wedge (about $20 \mathrm{~km}$ south of Mt Allan) and Mt Leichhardt (to the north of Coniston). While resident on Mt Allan they had learned the rituals appropriate to women's ceremonies in two of the main territories within the lease. Their husbands had played highly significant roles in transmitting this knowledge. Most were Jangalas who were kurdungurlu for honey-ant dreaming sites associated with western Mt Allan. But, because for decades they were the only Aboriginal residents on the station, they had also carried much of the lore concerning other parts of the lease. Such information included the basic stories, songs and paintings central to both men's and women's rituals concerning land. They had passed on the appropriate knowledge to their wives who had maintained it ever since. During the land claim process these women transferred much of this lore to other women who, by descent, were the recognised owners of the country but who had for years been resident elsewhere. The women as a group discussed at length the inclusion of these Nungarrayis in the list of owners, and finally decided to place them as responsible for 

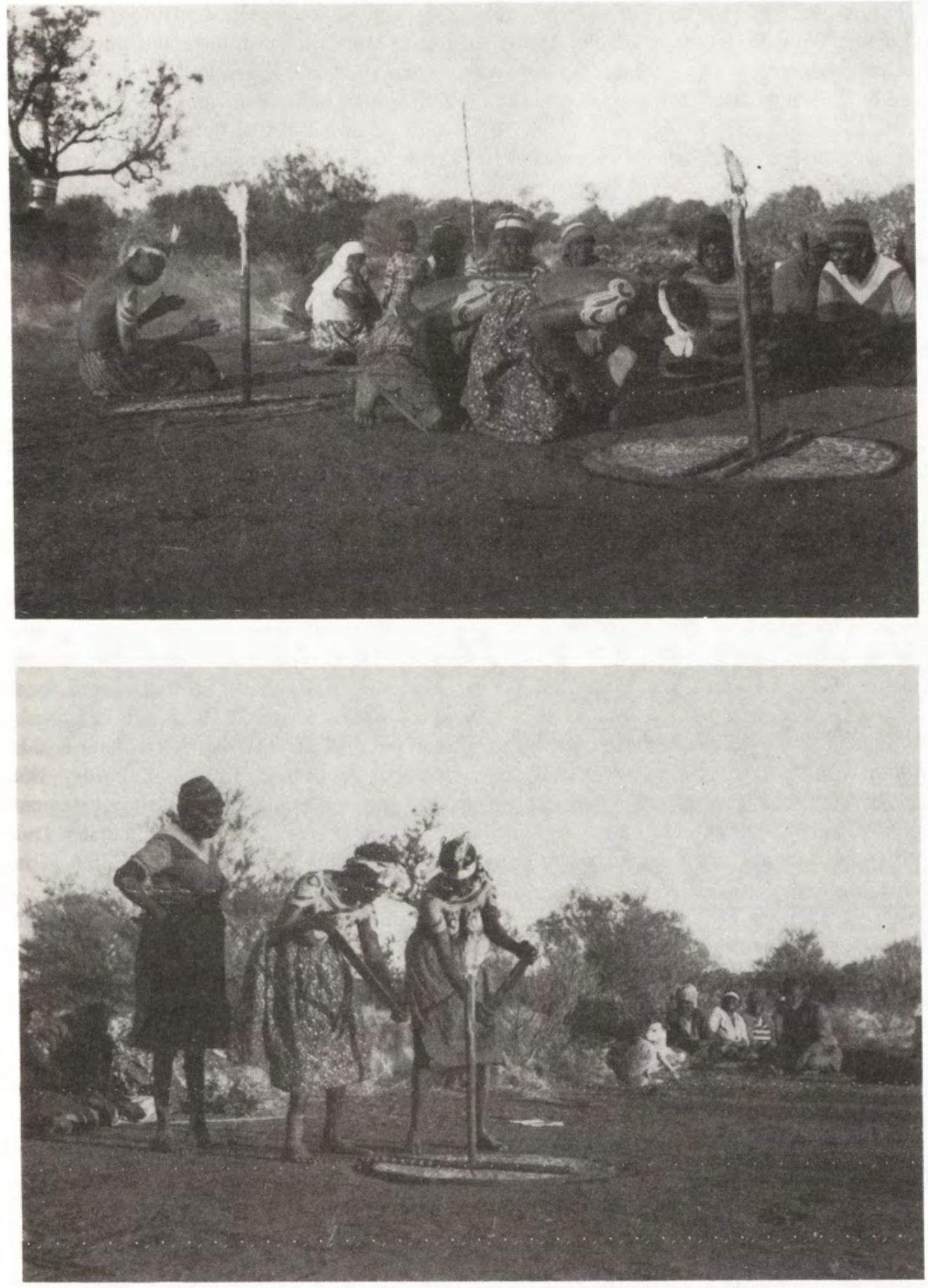

Napangardi and Nungarrayi perform yawulyu ceremonies for Mt Allan country. Performers and organisers include women resident elsewhere and longterm Mt Allan residents who have carried ceremonial responsibility. 
the $\mathrm{J} /$ Nungarrayi country because they belonged to the same subsection. Although evidence for their knowledge was strong the Aboriginal Land Commissioner in the end dismissed their claim because it was not 'based in any way on any principle of descent'. ${ }^{15}$ However two other claimants, also put forward because of long residence and the obvious practice of ritual necessary for primary spiritual responsibility, were accepted. The difference here was that these individuals could also claim a descent principle, in both cases based on association with shared mythical ancestors whose dreaming tracks passed through both the country of their parents and through Mt Allan. The Aboriginal Land Commissioner this time accepted that 'Perceived descent from a common mythic ancestor is a principle of descent which conveys the notion of common ancestry ... deemed by the members of the group to be relevant for recruitment to the group'. ${ }^{16}$

Thus, while length of residence in itself was not sufficient, that coupled with a definition of descent held by the Anmatyerre themselves was acceptable. This enabled a decision within the terms of the Act, but, as the Aboriginal Land Commissioner acknowledged, the failure to find a legal means of including the Nungarrayis indicated that the Act itself might not fully represent Anmatyerre social reality. In other words in this case the Act could not deal with cases arising through circumstances caused largely by Aboriginal resettlement in historical times.

\section{Ti Tree.}

Anmatyerre from Ti Tree, like their kin and friends at Mt Allan, have also experienced marked changes in residential patterns because of the establishment of non-Aboriginal pastoral properties. But in contrast to Mt Allan, Ti Tree station, because it was set up before many of the neighbouring properties such as Anningie, Willowra or Stirling, was a focal place for Aboriginal visitors from around 1920. Many who then came to work on the property, and to bring up their children at the original homestead at Tea Tree Well or later beside the new homestead adjacent to the Hanson River, were Anmatyerre from that country. But some came from further afield and did not, in conventional terms, belong to local descent groups. However their descendants were included as claimants in the Ti Tree land claim. One of these families is today represented by the widow, children and grandchildren of an Arrernte man from Yambah (close to Alice Springs) who was one of the first 'boss' stockmen on Ti Tree. All except his widow, Nangala, were born on the property, and all the adults clearly played an important part in local ceremonial life. Their application for recognition as claimants was primarily based on the perception by the rest of the community that they performed this role, and also, with younger members of the family, that they were conceived and born on Ti Tree. In Nangala's case another factor was her traditional ownership of sites on Mt Barkly to the west, sites associated with the bush plum dreaming track which also traverses Ti Tree. These arguments were accepted by the Aboriginal Land Commissioner. ${ }^{17}$ But the names of other claimants, also put forward by the community because of long residence on the station, were excluded. In those cases, as with the Nungarrayis on Mt Allan, knowledge was not a sufficient cause for recognition of traditional ownership.

15 Aboriginal Land Council 1985:12.

16 Aboriginal Land Council 1985:11.

17 Aboriginal Land Council 1987:29-30. 
There was no proof of descent by any recognisable principle.

Resettlement had also affected the ritual knowledge held by people who clearly belonged to local descent groups on Ti Tree. Some of the more recent history of population movement within the area is of interest in this case. In the early 1970s, when negotiations over the purchase of the property by the Aboriginal Land Fund Commission first began, the Aboriginal population of $\mathrm{Ti}$ Tree was concentrated in a single main camp, beside the station homestead. Although some families in this camp were interested in moving eastwards to Woolla Downs, formerly a separate lease but incorporated into Ti Tree in the late 1950s, they had not been encouraged to do so, although that location was close to significant sites for which they were responsible. During this period two applications for excisions of small areas of the property were also granted. One was for an area of one square mile for the establishment of a new settlement for Aboriginal families who had long been living on Aileron station, Ti Tree's southern neighbour. By August of 1975 this community, Pmara Jutunta, commonly called New Place, had a population of around 120 . Because it was a planned community, on a sub-lease of land held within a non-Aboriginal owned pastoral station, it was seen by all outsiders at least, as completely separate from the Aboriginal community at Ti Tree homestead. This distinction was further emphasised by New Place's association with the Lutheran Finke River Mission and its strong anti-drinking stance. When Ti Tree became an Aboriginal property the independence of New Place was still stressed, and in fact early discussions about the presentation of the land claim were marked by anxieties as to whether this group would oppose or disrupt the process. Some people assumed that when Ti Tree became Aboriginal freehold land this Aileron mob would be told to 'go back to where they belonged'. The realities proved to be somewhat different.

Early discussions about the families of Ti Tree's traditional owners revealed that some of the key figures, both men and women, lived at New Place and were in fact members of the Aileron mob. It transpired that their years of residence at Aileron had been a classic case of the development of an attachment to a particular employer, and working on a specific station, a characteristic which appears time and time again in the workforces of long-established central Australian cattle stations. Children and grandchildren had been brought up on Aileron, and visits back to country on Ti Tree had been infrequent and often short. Women in particular had rarely come back. When they returned to Ti Tree in 1975 their links with their kin who had remained there were reinforced, but ceremonial life, partly because of the mission influence, remained fairly inactive. The land claim process changed this situation. A resurgence of interest in ritual, and particularly with places associated with ancestral beings, drew the traditional owners from New Place increasingly into prominence and eventually they became highly enthusiastic about reinforcing their knowledge of the stories they had been told by their own older relatives. They also participated in ceremonies, and some older women who initially had said firmly that they could not dance because they had never learned how to perform the rituals, were eager to take part. This educational process, a filling in of information which, because of resettlement, had not been transferred to two entire generations, was carried out by senior people from the Ti Tree community. As at Mt Allan these teachers included some long-term residents not recognised as members of local descent groups although many of the teachers were traditional owners. 


\section{Population Movement and Land Responsibilities - Dealing with a problem}

These brief examples illustrate how Anmatyerre people in central Australia have dealt with some of the problems affecting their care of the land, problems which have stemmed primarily from their resettlement following non-Aboriginal settlement within their country. They have essentially made the best of whatever situation in which they found themselves. Where they have had to accept living far from their own ancestral country they have, if they have had the appropriate skills, learned the lore necessary to look after their new country; and when the opportunity arose they have transferred this information back to those who, like themselves, moved away and could not return. If they were fortunate enough to remain in the country of their ancestors, they then ensured that they not only maintained the necessary knowledge, but also passed it on to others where appropriate. These strategies were not new. They were undoubtedly used in the past when population groups became non-viable. But they were adapted to a new situation, a situation where far more Anmatyerre than ever before had to live away from their land and under pressures which made it very difficult for them to care for that land as they felt necessary. An important message emerging from this is the universal belief which the Anmatyerre, and indeed all other Aborigines, had that all country must be cared for. And caring for country was first and foremost a spiritual affair, through which its ecological and environmental future would be assured.

The land claim processes for these two Anmatyerre groups also cast further light on the whole problem of the correspondence between the definition of 'traditional owners' and 'primary spiritual responsibility' as enshrined in non-Aboriginal legal terms, and the Aboriginal interpretation of these terms. Despite the considerable degree of flexibility with which successive Aboriginal Land Commissioners have used the terms, there is still a lack of correspondence. This brief description of settlement history, and subsequent assumptions of ritual responsibility, further illustrates the important interconnections between anthropological understanding and historical inquiry.

\section{BIBLIOGRAPHY}

Aboriginal Land Commissioner. Claim by the Warlpiri and Kartangarurne-Kurintji Canberra, 1979. Anmatjirra and Alyawarra land claim to Utopia pastoral lease. Canberra, 1980a.

Lander Warlpiri Anmatiirra land claim to Willowra pastoral lease. Canberra, $1980 \mathrm{~b}$.

Mt Allan land claim. Canberra, 1985.

Ti-Tree Station land claim. Canberra, 1987.

Cribben, J. The killing times. Sydney, 1984.

Green, J., R. Hagen, J. Spierings and E. Young. The Anmatyerre land claim to Ti Tree pastoral lease and associated areas. Claim book prepared on behalf of the traditional owners of the area on the instruction of the Central Land Council. Alice Springs, 1984.

Hiatt, L.R. 'Introduction', in L.R. Hiatt ed., Aboriginal landowners. Oceania Monograph no.27, pp 1-10. Sydney, 1984a.

'Traditional land tenure and contemporary land claims', in L.R. Hiatt ed., Aboriginal landowners. Oceania Monograph no. 27, pp11-23. Sydney, 1984b.

Layton, R. 'Ambilineal descent and traditional Pitjantjatjara rights to land', in N. Peterson and M. Langton eds, Aborigines, land and land rights. Canberra, 1983.

Meggitt, M.J. Desert people. Sydney, 1962.

Peterson, N. and E. Young. Land claim to Mt Allan pastoral lease. Claim prepared at the instruction of the Central Land Council on behalf of the claimants. Alice Springs, 1982.

Spencer, W.B. Wanderings in wild Australia. London, 1928.

Toohey, J. Seven years on. Canberra, 1984. 